\title{
Preg-robbing of Gold by Carbonaceous Materials Encountered in Gold Processing*
}

\author{
${ }^{1}$ F. Amanya, ${ }^{1}$ G. Ofori-Sarpong, ${ }^{1}$ V. Anni, ${ }^{1}$ R. K. Amankwah \\ ${ }^{1}$ University of Mines and Technology, P. O. Box 237, Tarkwa, Ghana
}

Amanya, F., Ofori-Sarpong, G., Anni, V. and Amankwah, R. K. (2017), "Preg-robbing of Gold by Carbonaceous Materials Encountered in Gold Processing”, Ghana Mining Journal, Vol. 17, No. 2, pp. 50 - 55.

\begin{abstract}
Processing of gold from refractory ores containing carbonaceous materials $(\mathrm{CM})$ poses challenges due to the ability of the $\mathrm{CM}$ to preg-rob dissolved gold. Depending on the type and maturity of CM encountered, preg-robbing of aurocyanide ion can lead to reduction in gold recovery ranging from a few percentages to more than $50 \%$. Knowledge on the type of $\mathrm{CM}$ present, and its capacity for gold adsorption is important in predicting pre-treatment methods that can deactivate the CM and reduce its ability to preg-rob. This paper, as part of an on-going work, presents results on the degree of adsorption by the various carbonaceous materials encountered in gold processing, and estimates the amount of aurocyanide complex pregrobbed by them. To do this, various weights of carbonaceous materials (wood chips, charcoal, barren carbon and fresh activated carbon) were contacted with gold solution for a given period of time. The percentages of gold adsorbed on the various carbons were determined, and the results showed an increasing trend of preg-robbing in favour of wood chips $<$ charcoal < barren carbon < activated carbon. Of all the CMs, wood chips have not undergone any carbonisation and/or activation, and thus exhibited the lowest affinity. The adsorption capacities in grams of gold per tonne of carbon over a 24-hr period were 30-65 for wood chips, 320-370 for charcoal, 410-420 for barren carbon and 580-650 for activated carbon. The trend shows direct correlation with the activities and the degrees of graphitisation and maturity of the various carbonaceous materials. It is thus important to characterise carbonaceous gold ores to know the maturity of the CM present, which will inform on the pre-treatment processes required.
\end{abstract}

Keywords: Preg-Robbing, Wood Chips, Charcoal, Activated Carbon

\section{Introduction}

Gold processing using cyanidation dates back to more than a century ago (Marsden and House, 2006). In the gold-cyanide system, several challenges are encountered depending on the type of gold ore being processed. Gold ores are generally categorised into two types namely, non-refractory and refractory. The non-refractory ores can easily be processed using direct cyanidation and/or gravity concentration. Refractory ores, on the other hand, are difficult to treat and require pre-cyanidation processes to liberate the gold and/or surface deactivation process to passivate the surface against preg-robbing of aurocyanide ion. The second aspect becomes extremely important when the ore contains carbonaceous material which behaves like activated carbon, and thus has the ability to adsorb aurocyanide from solution (Osseo-Asare et al., 1984; Hausen and Bucknam, 1985; Pyke et al., 1999; Van Vuuren et al., 2000; Schmitz et al., 2001; Amankwah et al., 2005; Marsden and House, 2006; Ofori-Sarpong et al., 2013a; 2013b), leading to reduction in gold recovery. The extent to which overall gold recovery reduces depends on the type of $\mathrm{CM}$ and the degree of maturation of the carbon, and the quantity available (Helm et al., 2009). In gold processing, various carbonaceous materials of different types and characteristics may be encountered, and these would affect gold recovery at different degrees. It has been reported that adsorption of gold onto the surface of carbon has a direct correlation with the degree of maturity and thus the well-developed graphitic structure (Jones et al., 1989; Ibrado and Feurstenau, 1992; Stenebraten et al., 2000; Ofori-Sarpong et al., 2010; 2013a).

Several researchers have reported on CM in gold ores to include charcoal, anthracite, graphite, coal, shale, decaying wood, wood ashes and other vegetable matter (Adams et al, 1996; Rees and van Deventer 2000; Schmitz et al., 2001; Tan et al, 2003; Ofori-Sarpong and Osseo-Asare, 2013). The carbonaceous materials can be grouped broadly into low, medium and high maturity carbons which can be conveniently represented by wood chips, charcoal and activated carbon respectively. In mining, wood chips are formed by the degradation of the timber used for roof supports in underground mines, and/or roots of vegetation cleared for surface mining. These wood chips cause a number of problems in the leaching circuit (Gray, 2006). These include blinding or blocking of the inter-stage screens, and overflow of pulp and loaded carbon on the screen. The above occurrences lower the gold loading on activated carbon introduced into the circuit intentionally to adsorb gold (Anon, 2015).

Plant and animal remains get buried and undergo degradation under high temperature and pressure in coalification process to generate coal and carbonaceous matter in gold ores (Van Krevelen, 1993; Ofori-Sarpong et al., 2010). Most of the 
carbonaceous matter which forms part of the ore can thus be represented by charcoal, as they are formed through similar processes. Elemental carbon may be from matured carbonaceous matter or released directly from the incomplete combustion of carboncontained materials such as coal, diesel, gasoline and biomass (Berg, 2010). The activated carbon used for gold adsorption undergoes desorption of gold producing barren carbon which is recycled for adsorption. During the process, there is disintegration of the carbon producing fines, which if not handled well, find their way back into the adsorption circuit and add to the abraded carbon generated in the leaching circuit. Such fine carbons have a high ability to preg-rob dissolved gold as they cannot be screen-separated for recovery (OforiSarpong et al., 2010).

The various carbonaceous materials of different types and characteristics encountered in gold processing result in lower gold recoveries and high tailings values. Determination of the amount of gold these carbonaceous materials can adsorb in leaching circuits, has not received adequate attention (Anon, 2015). Ascertaining and documenting the extent to which these carbonaceous materials interact with aurocyanide complex and reduce gold recovery will therefore help mining companies in taking major decisions, and researchers in answering research questions in this area. This paper thus sought to investigate the extent to which various carbonaceous materials, encountered in gold processing, preg-rob aurocyanide complex.

\section{Resources and Methods Used}

\subsection{Materials}

Ore samples used for this study were obtained from the Tarkwaian and Birimian rock systems of Ghana. Wood chips were generated from teak that is used for underground supports and the roots of common plants in the mining zone of Tarkwa that easily gets mixed with the ore. The charcoal was obtained from Charcoal producers from Bonsa, near Tarkwa. Reagent grade sodium cyanide, calcium hydroxide and Chemquest activated carbon were utilized. Fig. 1 shows some of the carbonaceous samples used in the experiment.

\subsection{Methods}

To obtain gold solution for the work, gold concentrate $(20 \mathrm{~g} / \mathrm{t})$ was leached with $300 \mathrm{~g} / \mathrm{L}$ sodium cyanide at $\mathrm{pH} 11$ and $50 \%$ solids for $24 \mathrm{~h}$. The gold solution obtained was diluted to $5 \mathrm{mg} / \mathrm{L}$ which was used for the experiment. The carbonaceous materials (wood chips, charcoal, barren and fresh activated carbon) were dried, ground and sieved to obtain $80 \%$ passing $106 \mu \mathrm{m}$ to mimic the grind size of $\mathrm{CM}$ in gold ores. Various weights of the materials $(0.05 \mathrm{~g}, 0.1 \mathrm{~g}, 0.5 \mathrm{~g}, 1.0 \mathrm{~g}$ and $2.0 \mathrm{~g}$ ) were contacted with $25 \mathrm{ml}$ of $5 \mathrm{mg} / \mathrm{L}$ gold solution at $\mathrm{pH} 11$ for a period of 1, 2, 4, 8 and 24 hours. After the contacting periods, the materials were filtered and the concentration of residual gold solution were determined using Varian AA240FS Atomic Absorption Spectrometer (AAS)

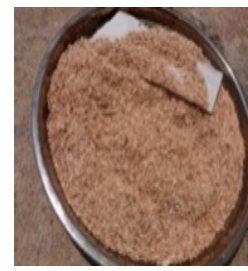

Wood Chips

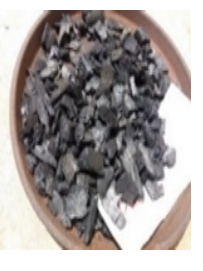

Charcoal

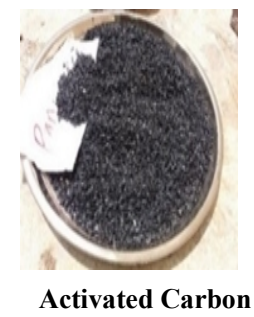

Fig. 1 Some CM Samples Used in the Experiment

\subsection{Analysis of Data}

The amount of gold adsorbed (preg-robbed) by the various carbonaceous materials, expressed as Pregrobbing Effect of Carbon (PEC) in $\mathrm{g} / \mathrm{t}$ (OforiSarpong et al, 2010), was determined by subtracting the concentration left in solution from the original concentration of gold used, and computed according to Equation 1.

$$
\text { PEC }\left(\text { in } \frac{\text { gram of gold }}{\text { tonne of carbon }}\right)=25 \mathrm{~mL} x\left(\left(I C_{A u}-F C_{A u}\right) \mu \mathrm{g} / \mathrm{mL}\right)\left(\frac{1}{W_{C} g}\right)
$$

In Equation 1, IC and FC are the initial and final concentrations of gold in solution, $\mathrm{Wc}$ is the weight of carbonaceous material used in the adsorption test, and $25 \mathrm{~mL}$ is the volume of gold solution used. The difference in PEC values between the various carbonaceous materials gives an indication of their preg-robbing capacity.

\section{Results and Discussion}

This paper focused on investigating the pregrobbing capacities of various carbonaceous materials encountered in gold processing. The materials were all ground to $80 \%$ passing $106 \mu \mathrm{m}$, and various weights ranging from $0.05 \mathrm{~g}$ to $2 \mathrm{~g}$ were contacted with $5 \mu \mathrm{g} / \mathrm{ml}$ gold solution for up to 24 hours. The preg-robbing abilities of wood chips, charcoal, barren and fresh activated carbons have been determined, and the results presented in the ensuing sections.

\subsection{Preg-Robbing of Gold by Wood Chips}

Fig. 2 presents the percentages of gold adsorbed on wood chips ground to $106 \mu \mathrm{m}$. Different masses of the wood chips $(0.1 \mathrm{~g}, 0.5 \mathrm{~g}, 1.0 \mathrm{~g}$ and $2.0 \mathrm{~g})$ were used to adsorb from $5 \mu \mathrm{g} / \mathrm{ml}$ gold solution. 


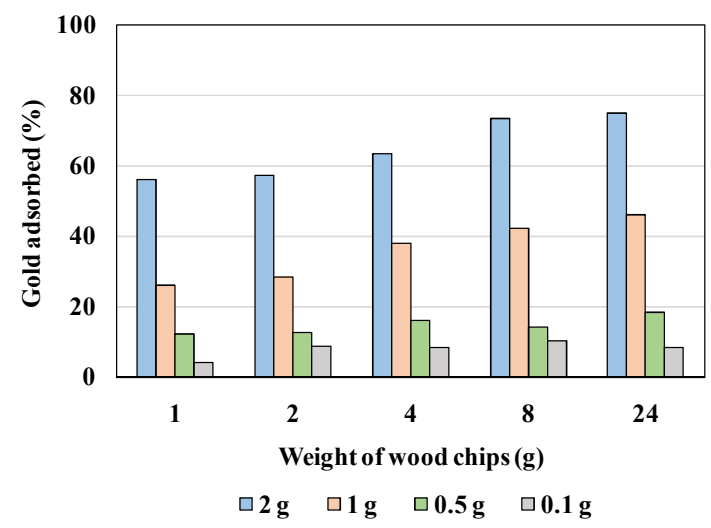

Fig. 2 Gold Adsorbed by Wood Chips as a Function of Time

The trend of adsorption was with respect to the masses of carbon used, and the contact time of adsorption. Adsorption was more pronounced when $2 \mathrm{~g}$ of the carbon was used, registering over $50 \%$ in one hour and over $70 \%$ of the original gold solution in 24 hours. On the other hand, $0.1 \mathrm{~g}$ of wood chips adsorbed a maximum of $10 \%$ in $8 \mathrm{hr}$ contact time. In terms of grams of gold per tonne of carbon material, wood chips adsorbed between 35 and 65 $\mathrm{g} / \mathrm{t}$ depending on the contact time. Even though the values are relatively low, it will still be prudent to avoid the entry of wood chips into leaching circuits as higher weights can contribute enormously to overall decrease in gold recovery.

\subsection{Preg-Robbing of Gold by Charcoal}

The percentages of gold adsorbed on charcoal ground to $106 \mu \mathrm{m}$ is depicted in Fig. 3. Different masses of the charcoal $(0.1 \mathrm{~g}, 0.5 \mathrm{~g}, 1.0 \mathrm{~g}$ and 2.0 g) were used for the adsorption, and the gold concentration was $5 \mu \mathrm{g} / \mathrm{ml}$. From Fig. 3, it can be observed that adsorption ranged between $70 \%$ and $98 \%$ depending on the weight of adsorbent used and roughly on the time of contact. Whereas the contact time did not present much influence, the weight of adsorbent did. For the $2 \mathrm{~g}$ of $\mathrm{CM}$, adsorption increased from $94 \%$ in one hour to $98 \%$ in 24 hours, whereas for $0.1 \mathrm{~g} \mathrm{CM}$, the corresponding values were $74 \%$ and $86 \%$. The percentages observed here are far higher than those realised in the case of wood chips. This is because charcoal is a charred version of wood, and the process of charring, similar to the coalification process, end up producing a more mature carbon material. This mature material will have a better developed pores and graphitic structure with less oxygen-containing groups required for gold adsorption (Ibrado and Feurstenau, 1992; Van Krevelen, 1993; Stenebraten et al., 2000; OforiSarpong et al., 2010; 2013a).

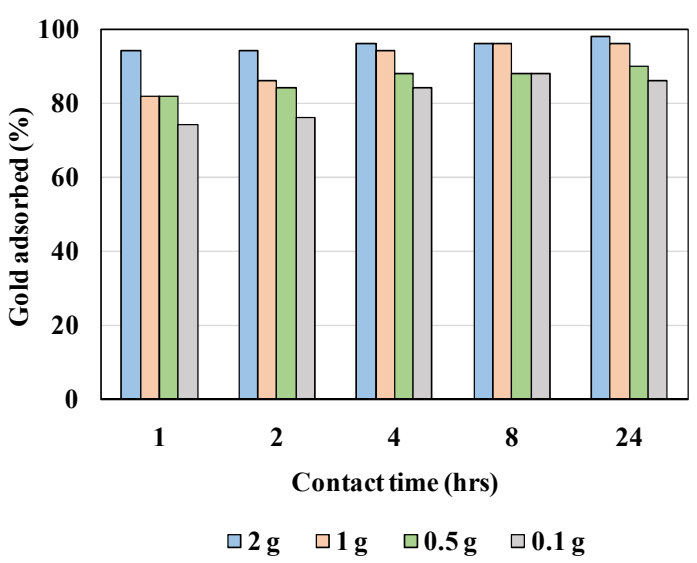

Fig. 3 Gold Adsorbed by Charcoal as a Function of Time

\subsection{Preg-Robbing of Gold by Barren Carbon}

Fig. 4 illustrates the percentages of gold adsorbed on barren carbon ground to $106 \mu \mathrm{m}$. The adsorption test was conducted by contacting different weights $(0.1 \mathrm{~g}, 0.5 \mathrm{~g}, 1.0 \mathrm{~g}$ and $2.0 \mathrm{~g})$ of barren carbon with $5 \mu \mathrm{g} / \mathrm{ml}$ gold solution.

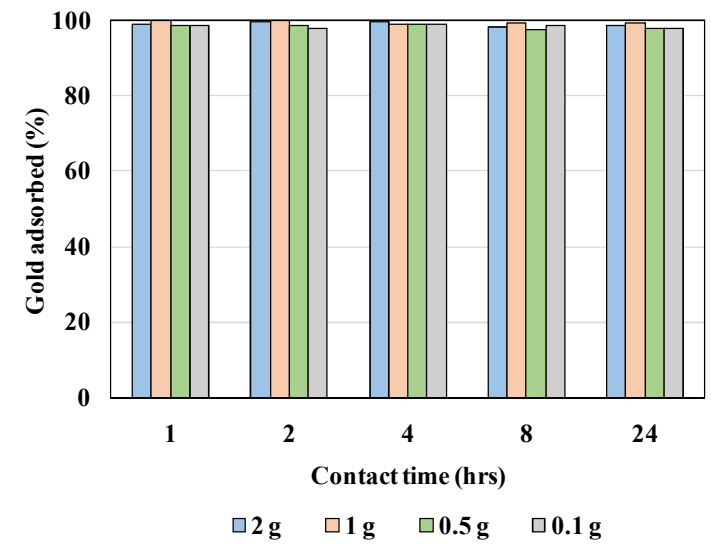

Fig. 4 Gold Adsorbed by Barren Carbon as a Function of Time

From the figure, it can be seen that the percentage adsorption was over $95 \%$ irrespective of the weight of adsorbent used and the contact time. Compared with wood chips and charcoal, which realised maximum adsorption of $74-86 \%$ and $94-98 \%$ respectively, barren carbon realised $97-100 \%$. The trend here is not out of place as the barren carbon can be seen as an originally activated product of charcoal, which has been used before for gold adsorption. In the production of activated carbon, carbonaceous precursors, such as wood, are dehydrated and charred to produce a charcoal-like material, which is activated to produce a skeletal material with well-developed internal structure for adsorption (Marsden and House, 2006). 


\subsection{Preg-Robbing of Gold by Fresh Activated Carbon}

Different masses of the activated carbon $(0.05 \mathrm{~g}$, $0.1 \mathrm{~g}, 0.5 \mathrm{~g}, 1.0 \mathrm{~g}$ and $2.0 \mathrm{~g}$ ) were contacted with 5 $\mu \mathrm{g} / \mathrm{ml}$ gold solution. Irrespective of the carbon weight and the time for adsorption, activated carbon adsorbed almost all the gold in solution, bringing the percentage adsorption to about $100 \%$. The percentage adsorptions on $0.05 \mathrm{~g}, 0.1 \mathrm{~g}$ and $1 \mathrm{~g}$ activated carbons have been demonstrated in Fig. 5. On the average, activated carbon adsorbed about one and half times as much as the barren carbon, which has some of its pores blocked by foulants.

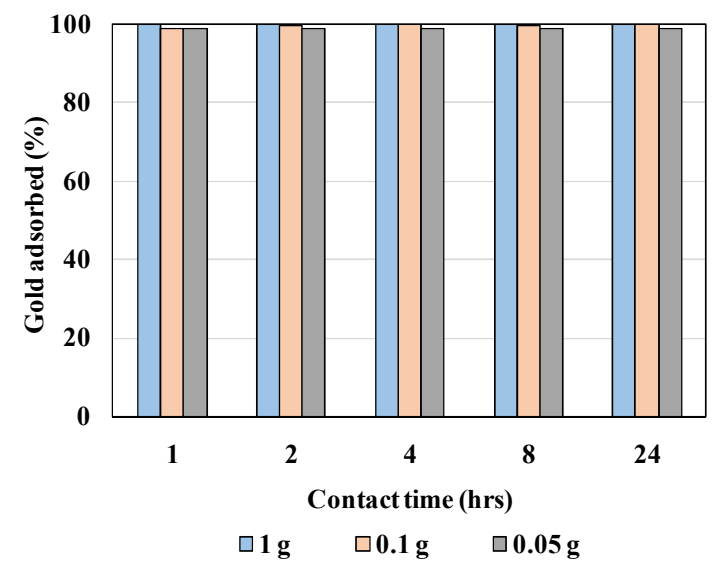

Fig. 4 Gold Adsorbed by Activated Carbon as a Function of Time

\subsection{Comparison of Preg-Robbing Effect of Various Carbonaceous Material}

The adsorption of gold by wood chips was not appreciable, and thus followed a pattern that is different from those of charcoal, barren carbon and activated carbon. This is due to the relatively low maturity of wood chips as a carbonaceous material (Ibrado and Feurstenau, 1992; Van Krevelen, 1993; Stenebraten et al., 2000; Ofori-Sarpong et al., $2010 ; 2013 a)$. To have a better way and more realistic way of comparing the adsorption capacities of the various carbonaceous materials encountered in gold processing, Equation 1, depicting the preg-robbing effect of carbon was used to generate values for wood chips, charcoal, barren carbon and fresh activated carbon. The results are illustrated in Fig. 6, which gives a clear increase in the adsorption values in $\mathrm{g} / \mathrm{t}$ in the order of wood chips (30-65), charcoal (320-370), barren carbon (410-420) and fresh activated carbon (580$650)$. As mentioned earlier, adsorption of gold has a direct correlation with the maturity, and hence the development of graphitic structure of carbon. In a paper by Ofori-Sarpong et al. (2010), the authors indicated that anthracite can adsorb several times more than lignite and bituminous coals due to the mature state of carbon in anthracite.

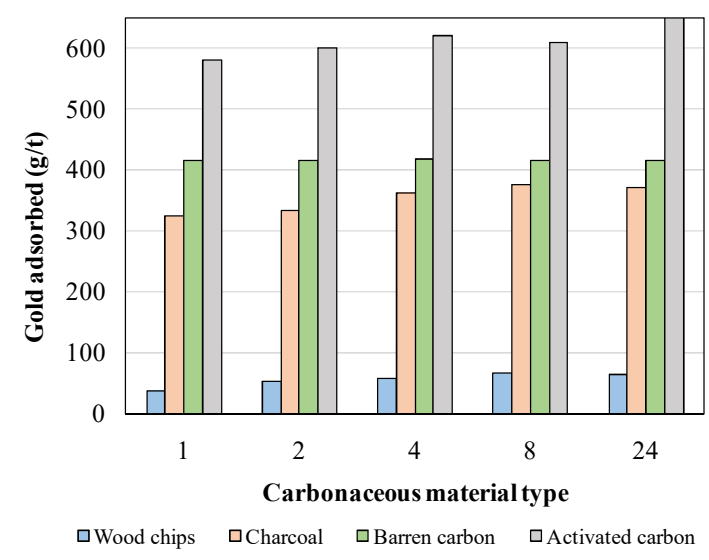

Fig.6 Comparison of Gold Adsorbed by Various Carbonaceous Materials

The values obtained in this paper show clearly that the maturity of elemental carbon in charcoal, barren carbon and activated carbon cannot be taken for granted as they can reduce gold adsorption drastically. It is also possible that higher gold concentrations can be affected even much more than the $5 \mu \mathrm{g} / \mathrm{ml}$ used here.

\section{Conclusions}

This paper presents results of part of an on-going work on mapping out the preg-robbing behaviour of gold ores. The degree of adsorption by the various carbonaceous materials encountered in gold processing were studied to determine the amount of aurocyanide complex preg-robbed by them. Various weights $(0.05-2.0 \mathrm{~g})$ of carbonaceous materials (wood chips, charcoal, barren carbon and fresh activated carbon) were contacted with gold solution for a given period of time ranging from 1 to 24 hours. The percentages of gold adsorbed on the various carbons were determined, and the results showed an increasing trend of preg-robbing in favour of wood chips $<$ charcoal $<$ barren carbon $<$ activated carbon. Further analysis gave a clear increase in the adsorption values in $\mathrm{g} / \mathrm{t}$ in the order of wood chips (30-65), charcoal (320-370), barren carbon (410-420) and fresh activated carbon (580$650)$. The trend shows direct correlation with the activities and the degrees of graphitisation and maturity of the various carbonaceous materials. Of all the CMs, wood chips have not undergone any carbonisation and/or activation, and thus exhibited the lowest affinity. It is thus important to characterise carbonaceous gold ores to know the maturity of the CM present, which will inform on the pre-treatment processes required.

\section{References}

Adams, M. D., Swaney, S. J., Fried, J. and Wagner, F. E., (1996), "Preg-robbing Minerals in Gold 
ores and residues", Hidden Wealth. S. African. Inst. Min. and Metall., Johannesburg, pp. 163172.

Amankwah, R. K., Yen, W.T. and Ramsay, J. (2005), "A Two-Stage Bacterial Pre-Treatment Process for Double Refractory Gold Ores", Mineral Engineering, Vol. 18, pp.103-108.

Anon, (2015), "Leaching and Adsorption", Research Handbook, www.wikipedia.com. Accessed: April 3, 2017.

Berg, R. D. (2000), "Inhibition of the PregRobbing Phenomenon in Gold Ore", Unpublished MSc Thesis Report, University of Cape Technikon, pp. 100-107.

Gray, E D. (2006), "A Quantitative Study into Carbon-In-Pulp Adsorption Operation", Unpublished MSc Thesis Report, University of Cape Technikon, pp. 17-85.

Hausen, D. M., Bucknam, C. H. (1985), "Study of Preg-Robbing in the Cyanidation of Carbonaceous Gold Ores from Carlin, Nevada", In:Proceedings of the Second International Congress on Applied Mineralogy, Park, W. C., Hausen, D. M. and Hagni, R. D. (Eds.), AIME, Warrendale, PA, pp. 833-856.

Helm, M., Vaughan, J., Staunton, W.P., and Avraamides, J. "An investigation of the carbonaceous component of preg-robbing gold ores. WorldGold Conference 2009", The Southern African Institute of Mining and Metallurgy, pp. 139-144.

Ibrado, A. S., Fuerstenau, D. W. (1992), "Effect of the Structure of Carbon Adsorbents on the Adsorption of Gold Cyanide", Hydrometallurgy, Vol. 30, pp. 243-256.

Jones, W. G., Klauber, C., Linge, H. G (1989), "Fundamental Aspects of Gold Cyanide Adsorption on Activated Carbon", In: Gold Forum on Technology and Practices - 'World Gold '89,Bhappu, R. B., Handen, R. J. (Eds)SME, Littleton, Co, pp. 278-281.

Marsden, J. House, I. (2006), "Ore Deposits and Process Mineralogy", The Chemistry of Gold Extraction, SME, pp. 40-276.

Ofori-Sarpong, G. and Osseo-Asare, K. (2013), "Preg-robbing of Gold from Cyanide and NonCyanide Complexes: Effect of Fungi Pretreatment of Carbonaceous Matter", International Journal of Mineral Processing, Vol. 119, pp. 27-33.

Ofori-Sarpong, G. and Amankwah, R.K., OsseoAsare, K. (2013a), "Reduction of Preg-Robbing by Biomodified Carbonaceous Matter-A Proposed Mechanism", Minerals Engineering, Vol. 42, pp. 29-35.

Ofori-Sarpong, G., Osseo-Asare, K. and Tien, M. (2013b), "Myco-Hydrometallurgy: Biotransformation of Double Refractory Gold Ores by the Fungus, Phanerochaete Chrysosporium", Hydrometallurgy, Vol. 137, pp. 38-44.
Ofori-Sarpong, G., Tien, M., Osseo-Asare, K. (2010), "Myco-hydrometallurgy: Coal Model for Potential Reduction of Preg-Robbing Capacity of Carbonaceous Gold Ores using the Fungus, Phanerochaete chrysosporium", Hydrometallurgy 102, 66-72.

Osseo-Asare, K., Afenya, P. and Abotsi, G. (1984), "Carbonaceous Matter in Gold Ores: Isolation, Characterization and Adsorption Behaviour in Aurocyanide Solutions", Precious Metals: Mining, Extraction and Processing, pp. 125144.

Pyke, B. L., Johnston, R. F., Brooks, P. (1999), "The Characterisation and Behaviour of Carbonaceous Material in a Refractory Gold Bearing Ore", Minerals Engineering, Vol. 12, pp. 851-862.

Rees, K.L. and Van Deventer, J. S. J. (2000), "Preg-robbing Phenomena in the Cyanidation of Sulphide Gold Ores", Hydrometallurgy, Vol. 58, pp. 61-80.

Schmitz, P. A., Duyvesten, S., Johnson, W. P., Enloe, L. and Mcmullen, J. (2001), "Adsorption of Aurocyanide Complexes onto Carbonaceous Matter from Preg-Robbing Goldstrike Ore", Hydrometallurgy, pp. 1-15.

Stenebraten, J. F., Johnson, W. P. and Mcmullen, J. (2000) "Characterisation of Goldstrike Ore Carbonaceous Material, Part 2: Physical characteristics. Minerals and Metallurgical Processing. Vol. 17, No. 1, pp. 7-15.

Tan, H., Feng, D. and Van Deventer, J. S. J. (2003), "Effect of Carbonaceous Coatings on Preg-Robbing of Chalcopyrite", Proceedings of Hydrometallurgy 2003 - Fifth International Conference, Young, C.A., Alfantazi, A.M., Anderson, C.G., Dreisinger, D.B., Harris, B. and James, A. (Eds), Pennsylvania, U.S.A, pp. $35-48$.

Van Krevelen, D.W. (1993), Coal: TypologyPhysics-Chemistry-Constitution, 3rd ed., Elsevier, Amsterdam, 771 pp.

Van Vuuren, C. P. J. Snyman, C. P. Boshoff A. J. (2000), "Gold Losses from Cyanide Solutions Part II: The Influence of the Carbonaceous Materials Presents in the Shale Material", Minerals Engineering, Vol. 13, pp. 1177-1181.

\section{Author}

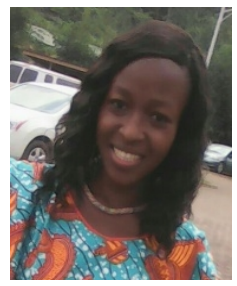

Felicia Amanya is currently a National Service Personnel at Goldfields Ghana Ltd, Tarkwa Mine. She holds BSc in Minerals Engineering from University of Mines and Technology, UMaT-Tarkwa, Ghana. Her research interest includes recovery of precious metals and extractive mettallugy. She is a member of Ghana Institution of Engineers and Society for Mining, Metallurgy and Exploration Engineers (SME). 


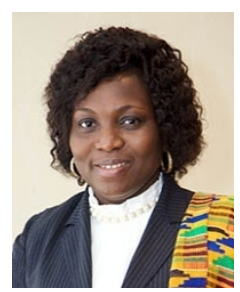

Grace Ofori-Sarpong is an Associate Professor of Minerals Engineering at the University of Mines and Technology, Tarkwa. She holds a PhD in Energy and Mineral Engineering from the Pennsylvania State University, an MSc in Environmental Resources Management and BSc in Metallurgical Engineering, both from the Kwame Nkrumah University of Science and Technology, KNUST, Kumasi, Ghana. Her areas of research interest include microbial-mineral interaction, water quality monitoring, acid mine drainage issues, microwaves in extractive metallurgy, bio-modification of recalcitrant organic matter and small-scale gold mining. She is a member of the Society for Mining, Metallurgy and Exploration Engineers (SME), Society of Petroleum Engineers (SPE), Graduate Women in Science (GWIS) and the West African Institute of Mining, Metallurgy and Petroleum (WAIMM)

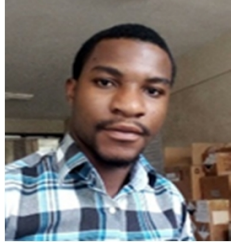

Victor Anni is a research assistant at Process Innovation Ghana. He holds a $\mathrm{BSc}$ in Minerals Engineering from the University of Mines and Technology, Tarkwa, Ghana. His research interests includes extractive metallurgical processes, recovery of precious metals and microbial mineral recovery.

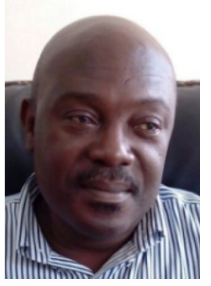

Richard K Amankwah is a Professor of Minerals Engineering at the University of Mines and Technology (UMaT), Tarkwa, Ghana. He holds a $\mathrm{PhD}$ degree in Mining Engineering from Queen's University, Canada, and MPhil and BSc in Metallurgical Engineering from the Kwame Nkrumah University of Science and Technology, KNUST, Kumasi, Ghana. His research interests include gold beneficiation, water quality management, microwave processing of minerals, small-scale mining, medical geology, microbial mineral recovery and environmental biotechnology. $\mathrm{He}$ is a Fellow of the West African Institute of Mining, Metallurgy and Petroleum (WAIMM), a member of the Ghana Institution of Engineers (GhIE) and Society for Mining, Metallurgy and Exploration Engineers. 